\title{
PERSEPSI MAHASISWA PADA EARNINGS MANAGEMENT \\ “STUDI KASUS MAHASISWA SEMESTER TUJUH \\ UNIVERSITAS SURABAYA, TAHUN 2017”
}

\author{
Jenifer \\ Universitas Surabaya \\ Jenifer301296@gmail.com \\ Yenny Sugiarti, S.E., M.Ak., QIA. \\ Universitas Surabaya \\ yenny_s@staff.ubaya.ac.id
}

\begin{abstract}
This study aims to determine students' perceptions of earningss management practices including student's perception about real earnings management, student's perception regarding accrual earnings management. In addition, this study also observe whether or not student perceive difference between real earnings management and accrual earnings management. This study used questionnaires and then the data obtained will be processed using descriptive statistics of mean and mode. The results of questionnaire data that have been processed will be deepened with Focus Group Discussion (FGD). The results of this study indicate that there is no difference in student perceptions for real earnings management practices and accrual earnings management.
\end{abstract}

Keywords: Real Earnings Management, Accrual Earnings Management

\section{PENDAHULUAN}

Earnings management merupakan suatu praktik yang digunakan untuk memperindah laporan keuangan dengan memanfaatkan kebijakan akuntansi yang ada. Praktik earnings management ini sudah ada sejak tahun 1940-an terbukti dari penelitian yang telah dilakukan oleh Hepwort (1953), karena pada tahun tersebut praktik earnings management menjadi perhatian bagi para peneliti untuk di teliti lebih dalam.

Praktik earnings management menimbulkan beberapa pandangan berdasarkan persepsi. Pandangan positif yaitu earnings management merupakan salah satu teknik untuk dapat memberikan informasi kepada manajer tentang keadaan perusahaan di masa yang akan datang (Ronen, 2008). Earnings management juga memiliki pandangan yang negatif karena juga dapat memberikan laporan keuangan palsu yang dapat menyesatkan pengguna laporan keuangan dalam mengambil keputusan (Pendarvis dan Morris, 2012). 
Persepsi Mahasiwa Pada Earnings Management "Studi Kasus Mahasiswa Semester Tujuh Universitas Surabaya, Tahun 2017”

Praktik earnings management ini dapat digunakan dengan dua cara yaitu accrual earnings management dan real earnings management. Metode accrual earnings management, manajer dapat memilih untuk menerapkan kebijakan akuntansi yang dapat digunakan sebagai alat untuk menaikan dan menurunkan laba. Metode real earnings management, menaikan atau menurunkan laba langsung menggunakan tindakan nyata sehingga ini sulit untuk diidentifikasi (Roychowdhury, 2006).Real earnings management langsung berpengaruh kepada arus kas dan berdampak pada image perusahaan di masa yang akan datang (Gunny, 2010).

Praktik earnings management erat pula kaitannya dengan integritas profesi akuntansi. Earnings management dinilai bersifat ambigu, karena itu dibutuhkan pendekatan kasus dalam pendidikan etika merupakan cara yang efektif untuk menyadarkan mahasiswa mengenai masalah dilematis secara etis dan untuk melatih pengambilan keputusan dalam kondisi tertentu (Falt, 1995) dalam (Martin, 2010). Mengingat lulusan mahasiswa jurusan akuntansi sebagian besar akan terjun dalam dunia profesi akuntansi. Karena itu peneliti menyadari pentingnya pandangan mahasiswa akuntansi mengenai earnings management, mengingat mahasiswa akuntansi yang ada pada saat ini nantinya akan terjun ke dunia kerja dan menjadi praktisi akuntansi. Sehingga sangat diperlukan mahasiswa yang memiliki integritas tinggi mengenai pandangan etis atau tidak suatu praktik earnings management.

Penelitian ini diharapkan dapat memperdalam penelitian sebelumnya (Cuzdriorean, 2013) mengenai presepsi mahasiswa terhadap earnings mangement pada mahasiswa jurusan akuntansi Fakultas Bisnis dan Ekonomika di Universitas Surabaya (UBAYA). Dimana penelitian ini dilakukan terhadap mahasiswa yang ada di Indonesia dengan sudut padang yang berbeda dari penelitian sebelumnya. Penelitian ini melihat secara lebih dalam mengenai earnings management yang dibagi menjadi real earnings management dan accrual earnings management.

Main research question dalam penelitian ini adalah "Bagaimana persepsi mahasiswa terhadap earnings management?”. Untuk menjawab main research question maka akan dibagi menjadi beberapa mini research question yaitu "Bagaimana persepsi mahasiswa terhadap real earnings management?”, “Bagaimana persepsi mahasiswa terhadap accrual earnings 
Persepsi Mahasiwa Pada Earnings Management "Studi Kasus Mahasiswa Semester Tujuh Universitas Surabaya, Tahun 2017”

management?”, “Apakah terdapat perbedaan persepsi mahasiswa terhadap real earnings management dan accrual earnings management?”.

\section{TELAAH TEORITIS}

\section{Pengertian Earnings Management}

Earnings management adalah keputusan memilih yang dilakukan oleh manajer melalui serangkaian pilihan kebijakan dan tindakan untuk mencapai target penjualan. Selain itu Scott (2015) mendefiniskan earnings management sebagai "the choice by a manager of accounting policies so as to achieve some specific objective" yang memiliki arti "pilihan yang dilakukan oleh manajer dalam menentukan kebijakan akuntansi untuk mencapai beberapa tujuan tertentu”.

Menurut Ronen (2008) penegertian earnings management dibagi menjadi tiga yaitu white, gray, dan black. Untuk white, earnings management mengambil keuntungan dari fleksibilitas dalam pilihan perlakuan akuntansi untuk memberikan sinyal kepada manajer mengenai arus kas di masa depan. Untuk gray, earnings management memilih perlakuan akuntansi yang bersifat oportunistik (hanya memaksimalkan tingkat ekonomis manusianya). Sedangkan black, earnings management adalah praktik yang menggunakan trik untuk salah menggambarkan atau mengurangi transparasi laporan keuangan.

\section{Real Earnings Management VS Accrual Earnings Management}

Real earnings management merupakan salah satu cara untuk melakukan manajemen laba dengan tindakan secara langsung. Sedangkan accrual earnings management merupakan manajemen laba dengan menggunakan keputusan manajer dalam menggunakan kebijakan akuntansi yang ada (Roychhowdhury, 2006). Sebenarnya real earnings management mengeluarkan biaya yang lebih besar apabila dibandingkan dengan accrual earnings management (Kim and Sohn, 2013), karena real earnings management berpengaruh langsung kepada arus kas perusahaan dan berdampak pada image perusahaan untuk masa yang akan 
Persepsi Mahasiwa Pada Earnings Management "Studi Kasus Mahasiswa Semester Tujuh Universitas Surabaya, Tahun 2017”

datang (Gunny, 2010). Praktik real earnings management juga sulit dideteksi oleh auditor karena merupakan tindakan langsung.

\section{Persepsi Etis terhadap Praktik Earnings Management berdasarkan Profesi}

Berdasarkan penelitian yang dilakukan Fischer dan Rosenzweig (1995) dalam jurnal Inggarwati dan Kaudin (2010) terhadap perbedaan persepsi earnings management antara mahasiswa S1, Mahasiswa MBA dan praktisi Akuntansi yang ada di Amerika Serikat. Ditemukan bahwa apabila dibandingkan dengan praktisi akuntan, mahasiswa lebih lunak dalam menilai etika manipulasi laba. Fisher dan Rosenzweig juga menemukan bahwa subyek penelitian mereka memiliki toleransi yang lebih besar kepada Real earnings management dibandingkan dengan accrual earnings Management. Karena kepekaan etika yang dimiliki responden lebih tinggi terhadap manipulasi akuntansi, responden menyadari bahwa kejujuran merupakan nilai etis yang mendasar. Sehingga Standar Akuntansi diadopsi untuk memastikan bahwa laporan keuangan memberikan cerminan akurat tentang kesehatan ekonomi suatu organisasi.

Elias (2002) mengatakan bahwa praktisi akuntansi lebih dapat memberikan toleransi mengenai real earnings management dibandingkan dengan mahasiswa akuntansi. Sedangkan untuk accrual earnings management baik praktisi akuntansi maupun mahasiswa akuntansi dipandang sebagai tindakan yang tidak etis, karena mahasiswa menyadari bahwa memanajemen laba dengan cara manipulasi pencatatan merupakanpraktik yang melanggar etika. Mahasiswa memiliki pemahaman ini karena Fakultas Akuntansi memiliki tanggung jawab untuk memberikan edukasi kepada mahasiswa mengenai etika dan kemungkinan konsekuensi yang diterima dari manipulasi laba.

Dalam studinya Rahmawati dan Sulardi (2003) dalam Inggarwati dan Kaudin (2003) melibatkan akuntan pendidik, mahasiswa akuntansi, dan manajer di Surakarta menemukan bahwa secara umum tidak terdapat perbedaan yang signifikan antara persepsi etis terhadap praktik earnings management dari akuntan pendidik, mahasiswa akuntansi dan manajer. 
Persepsi Mahasiwa Pada Earnings Management "Studi Kasus Mahasiswa Semester Tujuh Universitas Surabaya, Tahun 2017”

Graham et al., (2005) menemukan bukti bahwa manajer lebih suka untuk melakukan praktik real earnings management dibanding accrual earnings management dengan alasan bahwa real earnings management lebih tidak ketat diperiksa oleh auditor maupun regulasi seperti pemerintah, serta memiliki probabilitas yang lebih tinggi untuk tidak terdeteksi meskipun aktivitas yang dilakukan memiliki pengaruh yang berdampak langsung terhadap ekonomi perusahaan.

Penelitian Cuzdriorean (2013) juga menyatakan bahwa mahasiswa memberikan toleransi yang lebih besar terhadap real earnings management dibandingkan dengan accrual earnings management. Karena mahasiswamelihat praktik earnings management yang etis dan bermoral dimana tindakan real earnings management dianggap lebih etis dibandingkan dengan tindakan accrual earnings management.

\section{METODE}

Penelitian ini menggunakan pendekatan kuantitatif yaitu dengan menggunakan statistik deskriptif uji mean dan modus. Dan juga menggunakan pendekatan kualitatif dengan metode explanatory. Peneliti ingin mengetahui dan menjelaskan lebih dalam mengenai persepsi mahasiswa terhadap earnings management dan tujuan dari penelitian ini adalah untuk menjawab research question yang telah diutarakan sebelumnya. Metode pengumpulan data dalam penelitian ini menggunakan kuesioner yang diberikan kepada responden.

\section{Sampel}

Sampel yang akan digunakan sebagai responden adalah mahasiswa jurusan akuntansi Universitas Surabaya (UBAYA) yang telah megambil mata kuliah Teori Akuntansi sebanyak 41 mahasiswa. Pembagian kuesioner hanya memperhatikan tahun angkatan, semester dan telah lulus mata kuliah Teori Akuntansi tanpa memperharikan nilai mahasiswa (semester 7) setelah semua responden mengisi kuesioner kemudian akan diambil 10 responden secara random untuk melakukan Focus Group Discussion (FGD) untuk mengetahui lebih dalam alasan mahasiswa memberikan pendapat. 
Persepsi Mahasiwa Pada Earnings Management "Studi Kasus Mahasiswa Semester Tujuh Universitas Surabaya, Tahun 2017”

\section{Kuesioner}

Kuesioner yang diberikan kepada responden berikan kasus terkait dengan praktik earnings management. Dalam kuesioner terdapat dua bagian yaitu praktik real earnings management dan praktik accrual earnings management. Responden akan memberikan pendapatnya setuju atau tidak setuju dengan kasus yang diberikan. Responden dapat memberikan pendapat dengan memberikan pendapat Sangat Setuju (1), Setuju (2), Netral (3), Tidak Setuju(4), Sangat Tidak Setuju (5). Hasil dari jawaban kuesioner akan diolah menggunakan statistik deskriptif yaitu uji mean dan modus. Masing-masing bagian berisikan 10 kasus praktik earnings management yang bervariasi dan beberapa kasus dipakai untuk melihat konsistensi dari jawaban responden. Namun setelah dilakukan uji validitas dan reliabilitas diketahui bahwa dua kasus dari setiap bagian tidak valid dan tidak reliabel sehingga hasil kuesioner pada kasus tersebut tidak diolah lebih lanjut.

\section{Focus Group Discussion (FGD)}

FGD dilakukan untuk mengetahui lebih dalam mengenai alasan responden dalam memberikan pendapat setuju atau tidak setuju pada praktik earnings management. FGD dilakukan bersama 10 responden yang akan dibagi menjadi 3 kloter dengan total waktu \pm 60 menit. Dalam FGD ini responden akan memberikan alasannya terkait dengan pendapat yang diberikan dalam kuesioner.

\section{HASIL DAN PEMBAHASAN}

\section{Real Earnings Management}

Berikut ini adalah hasil dari kuesioner terkait dengan praktik real earnings management : 
Persepsi Mahasiwa Pada Earnings Management "Studi Kasus Mahasiswa Semester Tujuh Universitas Surabaya, Tahun 2017”

Tabel 1. Hasil Kuesioner REM

\begin{tabular}{|c|c|c|c|c|c|c|c|}
\hline Pernyataan & $\begin{array}{c}\text { Sangat } \\
\text { Setuju (1) }\end{array}$ & Setuju (2) & $\begin{array}{c}\text { Netral / } \\
\text { Ragu - } \\
\text { ragu (3) }\end{array}$ & $\begin{array}{c}\text { Tidak } \\
\text { Setuju (4) }\end{array}$ & $\begin{array}{c}\text { Sangat } \\
\text { Tidak } \\
\text { Setuju (5) }\end{array}$ & Total & Average \\
\hline A2 & 8 & 17 & 9 & 7 & - & 41 & 2,365854 \\
\hline A3 & 3 & 8 & 8 & 18 & 4 & 41 & 3,292683 \\
\hline A4 & 2 & 13 & 10 & 13 & 3 & 41 & 3,04878 \\
\hline A7 & - & 18 & 5 & 17 & 1 & 41 & 3,02439 \\
\hline A8 & - & 10 & 5 & 22 & 4 & 41 & 3,487805 \\
\hline A9 & 4 & 4 & 4 & 22 & 7 & 41 & 3,585366 \\
\hline A10 & 1 & 5 & 9 & 22 & 4 & 41 & 3,560976 \\
\hline Jumlah & 18 & 75 & 50 & 121 & 23 & & 4 \\
\hline
\end{tabular}

Dari tabel 1 dapat dilihat bahwa rata-rata dari real earnings management berkisar antara 2,3 sampai 3,5. Dan modus untuk sangat setuju dan setuju sebesar 93, serta tidak setuju dan sangat tidak setuju sebesar 144. Untuk modus netral tidak akan digunakan dalam penelitian ini.

\section{Accrual Earnings Management}

Berikut ini adalah hasil dari kuesioner terkait dengan praktik accrual earnings management :

Tabel 2. Hasil Kuesioner REM

\begin{tabular}{|c|c|c|c|c|c|c|c|}
\hline Pernyataan & $\begin{array}{c}\text { Sangat } \\
\text { Setuju (1) }\end{array}$ & Setuju (2) & $\begin{array}{l}\text { Netral / } \\
\text { Ragu - } \\
\text { ragu (3) }\end{array}$ & $\begin{array}{c}\text { Tidak } \\
\text { Setuju (4) }\end{array}$ & $\begin{array}{c}\text { Sangat } \\
\text { Tidak } \\
\text { Setuju (5) }\end{array}$ & Total & Average \\
\hline B1 & 2 & 17 & 9 & 11 & 2 & 41 & 2,853659 \\
\hline B2 & 2 & 14 & 4 & 18 & 3 & 41 & 3,146341 \\
\hline B4 & 4 & 8 & 5 & 20 & 4 & 41 & 3,2922683 \\
\hline B5 & 3 & 7 & 5 & 23 & 3 & 41 & 3 \\
\hline B7 & 2 & 14 & 4 & 19 & 2 & 41 & 3,121951 \\
\hline B8 & 3 & 14 & 3 & 16 & 2 & 38 & 3 \\
\hline B9 & 3 & 4 & 6 & 23 & 5 & 41 & 3,560976 \\
\hline Jumlah & 19 & 78 & 36 & 130 & 21 & & \\
\hline
\end{tabular}


Persepsi Mahasiwa Pada Earnings Management "Studi Kasus Mahasiswa Semester Tujuh Universitas Surabaya, Tahun 2017”

Dari tabel 1 dapat dilihat bahwa rata-rata dari accrual earnings management berkisar antara 2,8 sampai 3,5. Dan modus untuk sangat setuju dan setuju sebesar 97, serta tidak setuju dan sangat tidak setuju sebesar 151. Untuk modus netral tidak akan digunakan dalam penelitian ini.

\section{PEMBAHASAN}

\section{Real Earnings Management}

Berdasarkan hasil mean yang telah didapat sebelumnya menunjukan bahwa mahasiswa ragu-ragu dengan praktik earnings management. Sebenarnya mean tersebut bukan menandakan bahwa mahsiswa ragu-ragu. Hal ini dapat terjadi karena responden terbagi menjadi dua kelompok dalam memberikan pendapat bila dilihat dari modus hasil penelitian. Sebagian responden setuju dengan praktik real earnings management, namun sebagian lainnya tidak setuju. Setelah dilakukan FGD setiap responden memiliki alasan masing-masing terkait dengan pendapat yang telah diberikan sebelumnya. Dalam memberikan pendapat setuju atau tidak setuju para responden mengalami perbedaan persepsi dalam menentukan tingkat materialitas, kurangnya pemahaman dan kebijakan manajerial. Dari hasil modus menunjukan mahasiswa cenderung tidak setuju dengan praktik real earnings management karena dinilai telah melanggar prinsip dan peraturan akuntansi yang berlaku.

Pada praktik real earnings management mahasiswa tidak memberikan toleransi terhadap praktik real earnings management. Karena mahasiswa memperhatikan tujuan dari dilakukannya praktik real earnings management. Praktik earnings management untuk tujuan oportunistik atau income smoothing dinilai tidak etis, karena tujuan tersebut hanya untuk kepentingan pihak tertentu. Selain itu, mahasiswa juga melihat nilai materialitas, bila nilai tersebut dianggap materialitas maka mahasiswa mengganggap tindakan tersebut tidak etis.

\section{Accrual Earnings Management}

Bila dilihat dari hasil mean sebelumnya menggambarkan bahwa mahasiswa ragu-ragu dengan praktik accrual earnings management. Namun bila dilihat dari modus penelitian 
Persepsi Mahasiwa Pada Earnings Management "Studi Kasus Mahasiswa Semester Tujuh Universitas Surabaya, Tahun 2017”

menunjukan bahwa mahasiswa terbagi menjadi dua kelompok. Yaitu kelompok yang setuju dan tidak setuju dengan praktik accrual earnings management. Responden dapat terbagi menjadi dua kelompok masing-masing responden memiliki alasannya sendiri dalam meberikan pendapat setuju atau tidak setuju. Responden juga memiliki perbedaan persepsi dalam menentukan tingkat materialitas, kurangnya pemahaman dan kebijakan manajerial.

Dari hasil modus menunjukan bahwa mahasiswa tidak memberikan toleransi terhadap praktik accrual earnings management. Karena mahasiswa memperhatikan tujuan dan peraturan akuntansi yang berlaku. Bila tujuannya merupakan income smoothing maka mahasiswa menilai praktik acrrual earnings management tidak etis. Selain itu, bila praktik earnings management melanggar peraturan akuntansi maka praktik tersebut dinilai tidak etis.

\section{Perbedaan Persepsi Mahasiswa antara Real Earnings Management dan Acctual}

\section{Earnings Management}

Dari hasil dan pembahasan sebelumnya menunjukan bahwa tidak terdapat perbedaan persepsi mahasiswa yang signifikan antara real earnings management dan accrual earnings management. Mahasiswa cenderung tidak memberikan toleransi pada tindakan yang dilakukan perusahaan dalam kasus yang diberikan. Karena tindakan tersebut dianggap melanggar prinsip dan peraturan akuntansi yang berlaku. Dalam memberikan pendapatnya responden memperhatikan tingkat materialitas, prinsip dan peraturan akuntansi yang berlaku dan kebijakan manajerial. Selain itu mahasiswa juga memperhatikan dampak yang akan terjadi pada perusahaan dimasa yang akan datang akibat tindakan yang dilakukan saat ini.

Penelitian ini berbeda dengan penelitian sebelumnya yaitu peneltitian Cuzdriorean (2013) yang menjelaskan bahwa mahasiswa memberikan toleransi yang besar terhadap real earnings management dibandingkan dengan accrual earnings management. Karena faktanya mahasiswa membuat keputusan berdasarkan hukum etik yang berlaku. Penelitian Cuzdriorean (2013) menggunakan mean yang dibandingkan dengan mean dari penelitian Bruns and Merchant (1990). Kemudian penelitian Vadie et al (2012) menyatakan bahwa mahasiswa menilai etis atau tidak suatu praktik earnings management berdasarkan tujuan dilakukannya 
Persepsi Mahasiwa Pada Earnings Management "Studi Kasus Mahasiswa Semester Tujuh Universitas Surabaya, Tahun 2017”

earnings management. Mahasiswa menilai praktik accrual earnings management lebih buruk dibandingkan dengan accrual earnings management.

Penelitian sebelumnya menggunakan mean untuk dibandingkan dengan penelitian Merchant (1990). Penelitian ini juga menggunakan mean namun hasil mean tidak dapat menggambarkan persepsi mahasiswa. Sehingga modus juga dilakukan dalam penelitian ini untuk melihat secara lebih dalam lagi. Penelitian ini juga menggunakan FGD untuk mengetahui alasan mahasiswa memberikan pendapat setuju atau tidak setuju terhadap praktik earnings management.

\section{Implikasi}

Hasil penelitian ini menunjukan bahwa tidak terdapat perbedaan persepsi mahasiswa terhadap praktik real earnings management maupun praktik accrual earnings management. Penelitian ini tidak sesuai dengan penelitian sebelumnya dimana masiswa lebih memberikan toleransi yang besar terhadap real earnings management dibandikan dengan accrual earnings management. Hal ini disebabkan peneliti tidak memperhatikan nilai mahasiswa yang menjadi responden. Kemudian sebagian responden memiliki pemahaman yang kurang tentang prinsip dan peraturan akuntansi.

Sehingga dalam penelitian ini diharapkan pihak pengajar dapat menjelaskan lebih dalam lagi mengenai praktik earnings management, prinsip dan peraturan akuntansi secara mendalam. Kemudian memastikan mahasiswa memiliki pemahaman yang cukup terkait prinsip dan peraturan akuntansi. Sehingga mahasiswa jurusan Akuntansi UBAYA memiliki persepsi yang benar terhadap earnings management dan akan membangun integritas mahasiswa.

\section{KESIMPULAN}

Pada penelitian ini mahasiswa memberikan pendapat tidak setuju pada praktik earnings management yang dilakukan perusahaan dalam kasus. Baik real earnings management maupun accrual earnings management yang dilakukan. Karena tindakan yang 
Persepsi Mahasiwa Pada Earnings Management "Studi Kasus Mahasiswa Semester Tujuh Universitas Surabaya, Tahun 2017”

dilakukan perusahaan dinilai telah melanggar prinsip dan peraturan akuntansi, serta mengandung nilai yang material. Nilai yang material dianggap dapat mempengaruhi laporan keuangan sehingga berpengaruh pada keputusan yang dibuat oleh pengguna informasi laporan keuangan. Penelitian sebelumnya yang dilakukan oleh Cuzdriorean (2013) menyatakan mahasiswa lebih memberikan toleransi kepada praktik real earnings management dibandingkan dengan accrual earnings management.

Hasil penelitian ini berbeda dengan penelitian sebelumnya karena dipengaruhi oleh beberapa faktor yaitu perbedaan persepsi mahasiswa dalam menentukan tingkat materialitas, pemahaman teori, dan kebijakan manajerial. Dari hasil penelitian ini mahasiswa menilai praktik earnings management merupakan tindakan yang etis dilakukan selama nilai yang terkandung tidak material, tindakan tersebut tidak melanggar prinsip dan peraturan akuntansi yang berlaku, dan bila tindakan tersebut merupakan kebijakan manajerial. Baik untuk penghematan pajak maupun untuk kelangsungan hidup perusahaan di masa yang akan datang.

\section{DAFTAR PUSTAKA}

Arel B., Beaudoin C., Cianci A., 2012. The Impact of Ethical Leadership, the Internal Audit Function and Moral Intensity on a Financial Reporting Decision, Journal of Business Ethics, volume 109, issue 3, pp. 351-366

Arens, Alvin A., Randal J. Elder, Mark S. Beasley. 2012. Auditing and Assurance Services: An Integrated Approach, 14th edition. London: Pearson.

Cuzdriorean, Dan Dacian., 2013. Students Attitudes Regarding The Ethics Of EarningssManagement Activities: An Empirical Investigation, volume 2, issue 15, 6

Elias, Rafik Z., 2002. Determinants of Earningss Management Ethics Among Accountants, Journal of Business Etchics, volume 40, pp. 35-45

Fischer M., Kenneth R., 1995. Attitudes of Students and Accounting Practitioners Concerning the Ethical Acceptability of Earningss Management

Geiger, Marshall A., Carmen Quirvan, and Alejandro Hazera, 2007. An International Comparison of Student Perceptions of Earningss Management: Evidence of Effects of National Origin between Mexico and the United,States Contaduria y Administracion 223, pp. 53-68

Graham, John R., Campbell R. Harvey., Shiva R., 2005. The Economic Implications of Corporate Financial Reporting 
Persepsi Mahasiwa Pada Earnings Management "Studi Kasus Mahasiswa Semester Tujuh Universitas Surabaya, Tahun 2017”

Gunny, Katherine A., 2010. The Relation Between Earningss Management Using Real Activities Manipulation and Future Performance: Evidence from Meeting Earningss Benchmarks, Cotemporary Accounting Research, Volume 27 No.3

Horngren, Charles T, Srikant M Datar, dan George Foster. (2006). Akuntansi Biaya Dengan Penekanan Manajerial Jilid 2 Edisi 12. Jakarta: Erlangga.

Inggarwati K., Arnold K., 2010. Persepsi Etis Pelaku Akuntansi Terhadap Praktik Manajemen Laba Berdasarkan Profesi Akuntansi Dan Jender, Jurnal Manajemen Teori dan Terapan, Tahun 3, No.3

Kieso, Donald E., Jerry J.W., Terry D. W., 2014. Intermediate Accounting : IFRS Edition, New York: John Wiley \& Sons

Kim, Joeng B., Byungcherl Charlie S., 2013. Real Earningss Management and Cost of Capital, Journal of Accounting and Public Policy

Leuz C., Nanda D., Wysocki P. D., 2003. Earningss management and investor protection. An international comparison, Journal of Financial Economics, volume 69, pp. 505-527

Martin, R., 2011. The CEO's ethical dilemma in the era of earningss management, Journal of Strategy \& Leadership, Vol. 39 Issue: 6, pp.43-47

Perdavis, Deborah M., David E. Morris, 2012. Analysis of the perceptions of accounting students and practitioners regarding the ethnicity of earningss management post Sarbanes-Oxley, Journal of Academic and Business Ethics

Roychowdhury, Sugata, 2006. Earningss management through real activities manipulation, Journal of Accounting and Economics 42, pp. 335-370

Scott, William R, 2015. Financial Accounting Theory. 7th edition. Pearson Canada Inc.

Sulistyanto, Sri, 2008. Manajemen Laba Teori dan Model Empiris, Jakarta : Grasindo

Skinner, Douglas J., Richard G.Sloan, 2002. Earningss Surprises, Growth Expectations, and Stock Returns or Don't Let an Earningss Torpedo Sink Your Portfolio, Review of Accounting Studies, 7, pp. 289-312

Trihendradi, Cornelius, 2011. Langkah Mudah melakukan Analisis Statistik Menggunakan SPSS 19, Yogyakarta : Andi

Trisnawati, R., Wiyadi, Noer Sasongko, 2012. Pengukuran Manajemen Laba: Pendekatan Terintegrasi 
Persepsi Mahasiwa Pada Earnings Management "Studi Kasus Mahasiswa Semester Tujuh Universitas Surabaya, Tahun 2017”

Vadiei, Mohammad H., Saleh A., Mohammad Reza A. Z., Ahmad Zendeh D., 2012. Survey effects of intent and materiality earningss management on ethical judgment of students in Iran, Journal of Business Administration, Vol 2,pp. 123-131

Warren, Carls S., Jamws M., Jonathan E. D., Novrys S., Devi Sulistyo K., Amir Abadi J., Chaerul D. D., 2014. Accounting Indonesia Adaption, Jakarta : Salemba Empat 